\title{
WEB SERIES OLAH NALAR (Perancangan Kampanye Sosial Seputar Isu Remaja Indonesia)
}

\author{
Aditya Utama \\ Program Studi Disain Komunikasi Visual \\ Jurusan Disain, FSR ISI Yogyakarta \\ aditya.oetama@gmail.com
}

\begin{abstract}
Olah Nalar is a social campaign trying to engage Indonesian youth to think more critically, smartly, and rationally in dealing with social issues that exist in their surrounding. The concepts that will be realized in this creation are divided into three parts, each of which represents three different social issues, namely: fanaticism, technological determinism, and violent behavior.

The format of these works is using communication campaign format and choosing web series as a medium platform. Simply put, web series is chosen because it is considered capable of accommodating the needs of the creator; from the communication aspect, the freedom of creativity, as well as the financial considerations.

In the process, these works try to present the aspects of novelty in the persuasion area by performing some experiments such as the use of soft persuasion style in the delivery of the message, relying on the aspects of logic as the foundation for the credibility of the message, and the use of visual closing at the end of each video.

Hopefully, the logical perspectives that are contained in the video are able to provide new awareness that can organize the perspective and behavior of the adolescent to become a better person individually and socially.
\end{abstract}

Keywords: adolescent, logical perspective, social campaign, web series..

Relevance to Visual Communication Design Practice: These works present several communication experiments. Hopefully, these experiments are able to offer a new perspective and novelty in the area of persuasion approach.

\section{PENDAHULUAN}

Masa remaja merupakan masa di mana seorang individu mengalami peralihan dari satu tahap ke tahap berikutnya dan mengalami perubahan baik emosi, tubuh, minat, pola perilaku, dan juga penuh dengan masalah-masalah (Hurlock, 1998). Oleh karenanya, remaja sangat rentan sekali mengalami masalah psikososial, yakni masalah psikis atau kejiwaan yang timbul sebagai akibat terjadinya perubahan sosial. Konflik yang dihadapi oleh remaja pun semakin kompleks seiring dengan perubahan pada berbagai dimensi kehidupan dalam lingkungan sekitar mereka.
Menurut Jean Piaget (dalam Santrock, 2001), perkembangan kognitif remaja merupakan periode terakhir dan tertinggi dalam tahap pertumbuhan operasi formal (period of formal operations). Pada periode ini, idealnya para remaja sudah memiliki pola pikir sendiri dalam usaha memecahkan masalah-masalah yang kompleks dan abstrak. Kapasitas berpikir secara logis dan abstrak mereka berkembang sehingga mereka mampu berpikir secara multi-dimensi. Para remaja tidak lagi menerima informasi apa adanya, tetapi mereka akan memproses informasi itu serta mengadaptasikannya dengan pemikiran mereka sendiri. Mereka juga mampu mengintegrasikan pengalaman masa lalu dan 
sekarang untuk ditransformasikan menjadi konklusi, prediksi, dan rencana untuk masa depan. Dengan kemampuan operasional formal ini, para remaja mampu mengadaptasikan diri dengan lingkungan sekitar mereka.

Namun pada kenyataan, di negaranegara berkembang seperti Indonesia masih banyak remaja yang belum mampu sepenuhnya mencapai tahap perkembangan kognitif operasional formal. Sebagian masih tertinggal pada tahap perkembangan sebelumnya, yaitu operasional konkrit, di mana pola pikir yang digunakan masih sangat sederhana dan belum mampu melihat masalah dari berbagai dimensi.

Hal ini bisa saja diakibatkan oleh sistem pendidikan di Indonesia yang cenderung menggunakan metode belajar-mengajar satu arah (ceramah) dan kurang memperhatikan perkembangan cara berpikir remaja. Penyebab lainnya bisa juga diakibatkan oleh pola asuh orangtua yang cenderung masih memperlakukan remaja sebagai anak-anak, sehingga remaja tidak memiliki keleluasan dalam memenuhi tugas perkembangan sesuai dengan usia dan mentalnya. Semestinya, seorang remaja sudah harus mampu mencapai tahap pemikiran abstrak supaya saat mereka lulus sekolah menengah, sudah terbiasa berpikir kritis dan logis serta mampu menganalisis masalah dan mencari solusi terbaik.

Ketertinggalan inilah yang mungkin menyebabkan semakin berkembangnya bentuk penyimpangan sikap dan perilaku yang dilakukan oleh remaja Indonesia. Permasalahan remaja saat ini tidak hanya berbentuk bolos sekolah atau tidak patuh pada orang tua, tetapi sudah mengarah pada tindakan kriminal, seperti tawuran pelajar yang menyebabkan kematian, perilaku seks bebas, penggunaan narkoba, dan lain-lain.

Sebagai bentuk antisipasi, remaja Indonesia harus dilatih untuk membiasakan diri menggunakan logika dalam menghadapi dan menelaah isu-isu sosial yang ada di lingkungan sekitarnya, tidak sekedar mengandalkan aspek emosi semata. Sebagai sebuah alat, logika mampu digunakan untuk mencapai sebuah kebenaran. Dalam definisi verbal, terdapat berbagai macam definisi tentang logika, namun hampir semua definisi menyimpulkan bahwa logika adalah aturan berpikir benar.

Sebagai ilmu, logika disebut dengan logike episteme (Latin: logica scientia) atau ilmu logika (ilmu pengetahuan) yang mempelajari kecakapan untuk berpikir secara lurus, tepat, dan teratur (Rapar, 1996: 9). Ilmu di sini mengacu pada kemampuan rasional untuk mengetahui, sedangkan kecakapan mengacu pada kesanggupan akal budi untuk mewujudkan pengetahuan ke dalam tindakan. Beberapa kegunaan logika antara lain:

1. Membantu setiap orang yang mempelajari logika untuk berpikir secara rasional, kritis, lurus, tetap, tertib, metodis, dan koheren.

2. Meningkatkan kemampuan berpikir secara abstrak, cermat, dan objektif.

3. Menambah kecerdasan dan meningkatkan kemampuan berpikir secara tajam dan mandiri.

4. Memaksa dan mendorong orang untuk berpikir sendiri dengan menggunakan asas-asas sistematis. 
5. Meningkatkan cinta akan kebenaran dan menghindari kesalahan-kesalahan berpikir, kekeliruan serta kesesatan.

Perancangan ini sengaja mengangkat logika sebagai fondasi pesan karena dinilai mampu menawarkan alternatif solusi terhadap permasalahan sosial remaja Indonesia. Sedangkan format perancangannya menggunakan format kampanye sosial dan memilih web series sebagai platform medianya.

Web series merupakan sebuah format acara berseri yang ditayangkan di media sosial berbentuk web TV, seperti: YouTube dan Vimeo. Web series biasanya didisain khusus untuk dirilis perdana via internet, bukan TV reguler. Setiap episodenya berdurasi sekitar satu hingga tujuh menit sehingga penonton tidak harus menunggu proses loading terlalu lama. Jenis dan format web series ada berbagai macam, seperti: fiksi, non fiksi, dokumenter, tutorial, video blogging, action, kartun, animasi, dan dengan genre yang sangat bebas. (http://www.koran-

jakarta.com/index.php/det

ail/view01/95178)

Web series dipilih karena dinilai mampu mengakomodir kebutuhan penulis; baik secara komunikasi, kebebasan berkreativitas maupun pertimbangan finansial produksi. Melalui web series, penulis dapat menciptakan karya audiovisual dengan biaya produksi yang relatif murah dan mampu merangkul audiens yang luas tanpa mengalami kesulitan dalam hal pendistribusian.

Pemilihan platform media ini juga dinilai sejalan dengan perilaku bermedia dari target audiens yang disasar. Dewasa ini, media sosial merupakan salah satu media yang populer dikonsumsi oleh kaum remaja Indonesia. Intensitas penggunaannya juga terbilang sangat tinggi. Berkat perkembangan teknologi, pengaplikasiannya bisa dilakukan di mana pun dan kapan pun. Beberapa karakter media sosial yang perlu diketahui menurut Mayfield dalam e-book What is Social Media (2008: 5) adalah:

\section{a. Participation}

Media sosial mendorong kontribusi dan feedback dari setiap orang yang tertarik untuk melakukannya. Hal ini mengaburkan batasan konvensional antara media dan audiens.

\section{b. Openness}

Media sosial terbuka terhadap feedback dan partisipasi. Mendorong voting, komentar, dan berbagi informasi. Jarang ada hambatan untuk mengakses dan memanfaatkan konten yang ada.

\section{c. Conversation}

Ketika media tradisional berlandaskan pada broadcast atau penyiaran (konten ditransmisikan atau didistribusikan kepada audiens), media sosial cenderung berlandaskan pada komunikasi dua arah.

\section{d. Community}

Media sosial memungkinkan komunitas terbentuk secara cepat dan berkomunikasi secara efektif. Komunitas mampu berbagi ketertarikan yang sama, seperti kecintaan terhadap fotografi, figur politik ataupun acara televisi favorit.

\section{e. Connectedness}

Sebagian besar media sosial berkembang berdasarkan kemampuan koneksi mereka, memanfaatkan hubungan link ke situs, sumber informasi dan orang.

Mempertimbangkan hal tersebut, perancangan kampanye ini sengaja 
mengandalkan media sosial sebagai medium penyampaian pesan karena dinilai strategis, efektif, dan mampu merangsang partisipasi. Sedangkan media sosial yang akan digunakan dalam kampanye ini adalah media web TV YouTube sebagai media utama dan menggunakan media sosial Facebook dan Twitter sebagai media promosi.

Kampanye sosial ini diberi nama Olah Nalar. Penamaan Olah Nalar terdiri dari kata "olah" yang mengisyaratkan adanya sebuah proses, baik berupa perumusan, perenungan ataupun pemikiran lebih mendalam. Sedangkan kata "nalar" merupakan kata lain dari akal atau logika. Jadi, Olah Nalar merupakan sebuah kampanye sosial yang menyajikan perspektif atau ajakan kepada kaum remaja Indonesia untuk melakukan perumusan, perenungan atau pemikiran logis dalam menyikapi isu sosial yang ada.

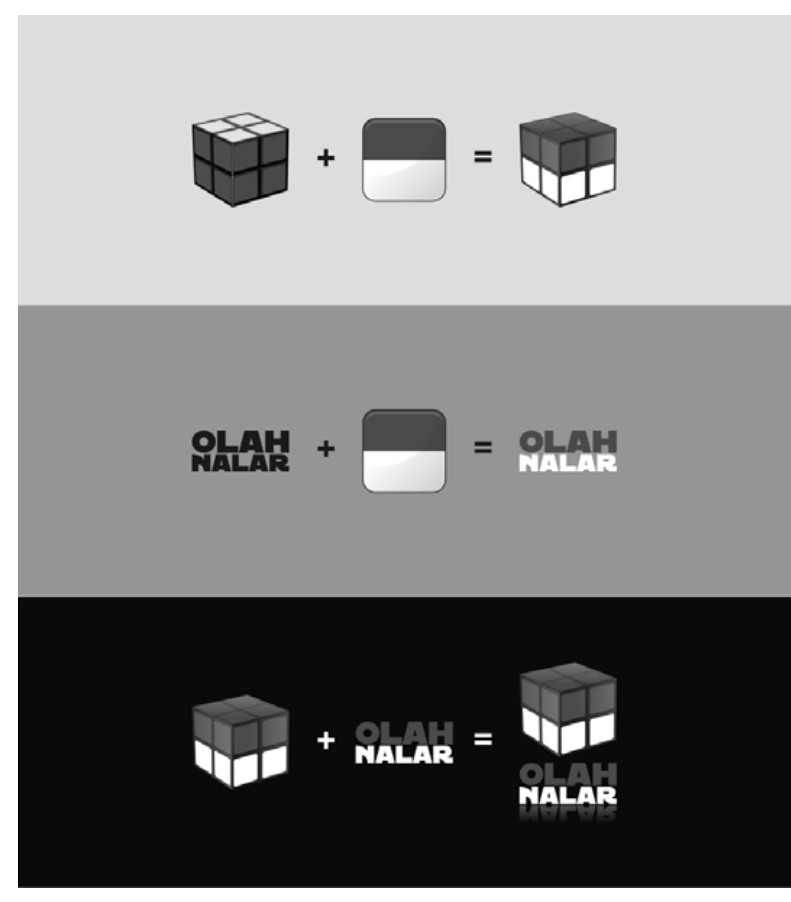

Gambar 1 Proses Pendesainan Logo Sumber: Aditya Utama, 2012

Materi dan argumen logis yang digunakan bersumber pada pemikiran pribadi terhadap realitas sosial di lingkungan sekitar yang sesuai dengan batasan topik yang akan diangkat. Secara sederhana, web series "Olah Nalar" merupakan sebuah argumen logis yang dikomunikasikan secara online melalui format audiovisual. Bersifat informatif dan menghibur, dapat berupa kritik, tips ataupun cara pandang terhadap sesuatu. Tidak bersifat mutlak, disajikan sebagai sebuah pendapat dan membuka sebuah perdebatan. Penggunaan genre maupun cara bertutur tidak dibatasi untuk memberikan ruang yang longgar bagi kompleksitas pemikiran yang akan diangkat. Selain itu, agar mampu memberikan unsur kesegaran dalam setiap penyajiannya dan terhindar dari aspek kemonotonan. 
Sementara itu, isu sosial yang diangkat dalam perancangan ini adalah fanatisme, ketergantungan teknologi, dan perilaku kekerasan. Ketiga isu sosial ini sengaja diangkat untuk memberikan contoh kasus tentang bagaimana aspek logika mampu berperan sebagai alat bantu yang dapat menyajikan perspektif baru dalam menelaah isu sosial yang ada.

Alur perancangan diawali dengan (1) analisis intrapersonal terhadap realitas sosial yang ada; dalam kasus ini adalah realitas sosial yang berkaitan dengan fanatisme,

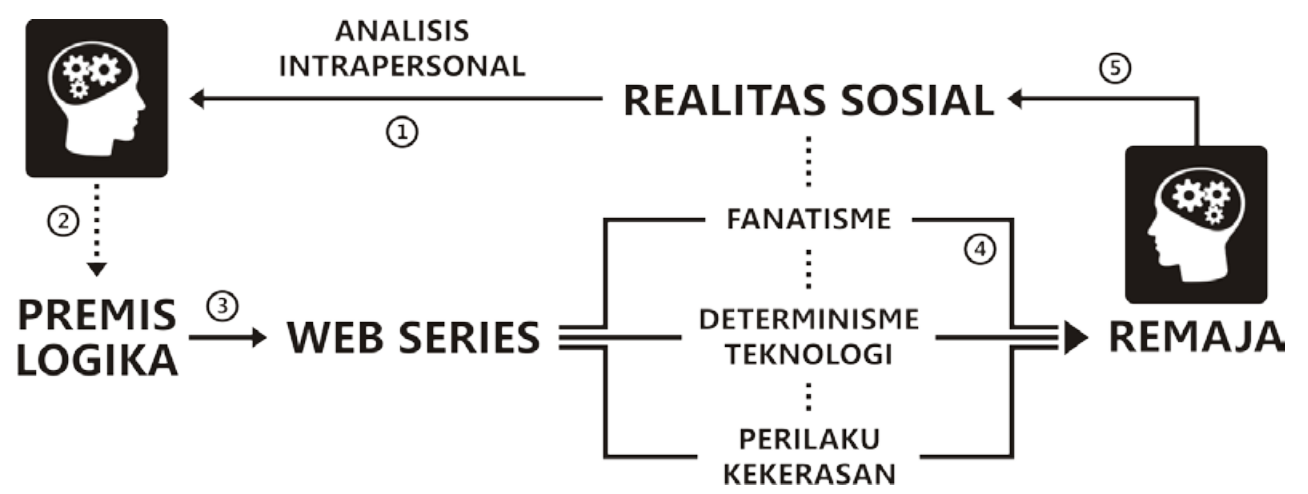

Gambar 2 Skema Kerangka Berpikir Sumber: Aditya Utama, 2013

ketergantungan teknologi, dan perilaku kekerasan. Analisis ini nantinya akan menghasilkan beberapa hipotesis intrapersonal yang diwujudkan dalam bentuk (2) premis logika. Premis logika ini kemudian diolah secara kreatif menjadi pesan komunikasi yang akan (3) disampaikan melalui media web series.

Ketiga isu sosial tersebut sengaja diangkat sebagai contoh kasus untuk memberikan gambaran kepada (4) kaum remaja tentang bagaimana logika mampu diposisikan sebagai alat bantu dalam mempertanyakan, merumuskan, dan menyikapi berbagai isu sosial yang ada. Harapannya, kebiasaan me-logika ini akan digunakan kaum remaja ketika (5) berhadapan dengan realitas sosialnya dan mampu memberikan kesadaran baru yang dapat menata cara pandang dan perilakunya untuk menjadi pribadi yang lebih baik secara individual maupun sosial.

\section{METODE PERANCANGAN}

Permasalahan yang harus dipecahkan pada perancangan web series Olah Nalar ini adalah bagaimana menemukan dan memilih konsepkonsep yang akan dieksekusi sesuai dengan kebutuhan serta identifikasi batasan yang telah ditentukan. Target audiens dalam perancangan ini adalah remaja Indonesia berjenis kelamin laki-laki dan perempuan, kisaran usia 15-22 tahun, memiliki account social media, dan aktif menggunakan internet.

Proses penggalian ide kreatif diawali dengan analisis intrapersonal terhadap realitas sosial yang ada di lingkungan sekitar. Berbagai macam insight intrapersonal yang 
telah ditemukan kemudian dikategorikan dan diturunkan menjadi ide-ide mentah yang akan dipilih dan diolah menjadi konsep menggunakan Brainstorming Personal DSKDB dan Teori Puzzle DSKDB.

\section{Brainstorming Personal DSKDB}

Dalam Brainstorming Personal DSKDB, pencarian ide dimulai dengan adanya kesadaran terhadap masalah yang ingin diatasi. Kesadaran akan permasalahan ini dengan sendirinya akan membentuk konsep relevansi yang akan membatasi proses pencarian ide. Setelah permasalahan sudah dapat dijabarkan dan batasan relevansi telah terbentuk, proses selanjutnya adalah brainstorming personal. Proses ini minimal dibagi menjadi tiga tahap yang terdiri dari:

\section{a. Tahap 1: Pemunculan Ide}

Dalam tahap ini, berbagai prospek ide dimunculkan secara tidak teratur, bebas, dan mentah berdasarkan pengetahuan dan/atau pengalaman yang ada. Konsep relevansi bersifat longgar agar tidak membatasi proses pemunculan ide. Pencipta lebih mengandalkan intuisinya untuk memutuskan ide-ide mana saja yang akan dimunculkan.

b. Tahap 2: Pemilihan dan Pengkerucutan Ide Dalam tahap ini, pencipta mulai memilahmilah berbagai ide yang ada dan mulai mengkerucutkannya berdasarkan relevansi (logika) dan intuisi (perasaan) secara seimbang. Ketat tidaknya filterisasi ide tergantung pada kemampuan dan jam terbang brainstorming pencipta. c. Tahap 3: Penurunan Ide ke Dalam Bentuk Konsep

Dalam tahap ini, ide-ide yang terpilih dirumuskan dan "diracik" menjadi lebih spesifik ke dalam bentuk konsep. Ide-ide yang terpilih bisa berdiri sendiri dan masing-masing membentuk konsep sendiri-sendiri atau bisa diintegrasikan ke dalam satu kesatuan bentuk konsep yang saling melengkapi. Setelah menentukan konsep, proses berikutnya adalah menerjemahkan konsep ke dalam aplikasi alat bantu eksekusi yang lebih konkrit, seperti naskah (copy) dan storyboard (visual). Setelah alternatif copy dan visual jadi, selanjutnya adalah melakukan seleksi dan revisi.

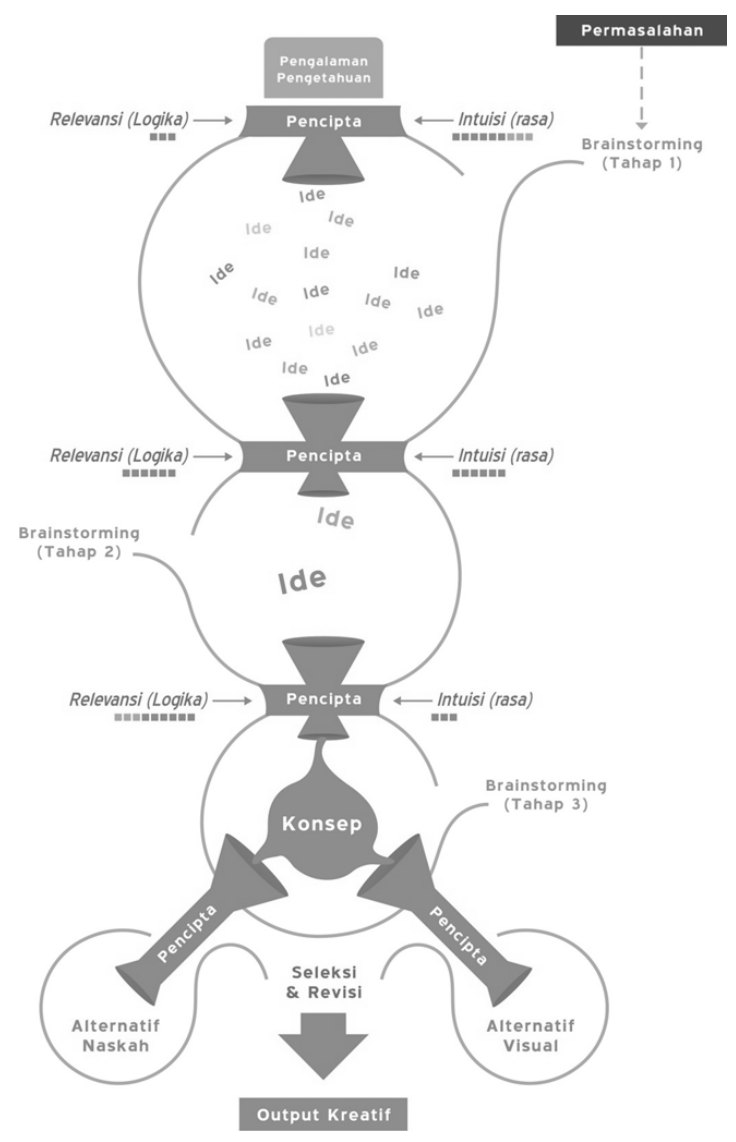

Gambar 3 Mekanisme Penciptaan Ide (Brainstorming Personal DSKDB) Sumber: Aditya Utama, 2011 


\section{Teori Puzzle DSKDB}

Teori Puzzle merupakan teori yang sengaja penulis ciptakan untuk menjelaskan proses penurunan konsep ke dalam bentuk naskah. Ibarat sebuah puzzle, naskah juga dapat dirumuskan dari berbagai potongan (fragmen) atau penggalan scene, visual dan/atau cerita yang pada awalnya belum terjabarkan dalam konsep namun dibutuhkan untuk melengkapi keutuhan naskah.
Potongan-potongan ini diperoleh dengan cara mempertanyakan celah-celah yang ada dalam konsep yang telah dihasilkan. Jawaban-jawaban yang diperoleh nantinya akan menjadi alat bantu untuk melengkapi kebutuhan naskah secara terperinci.

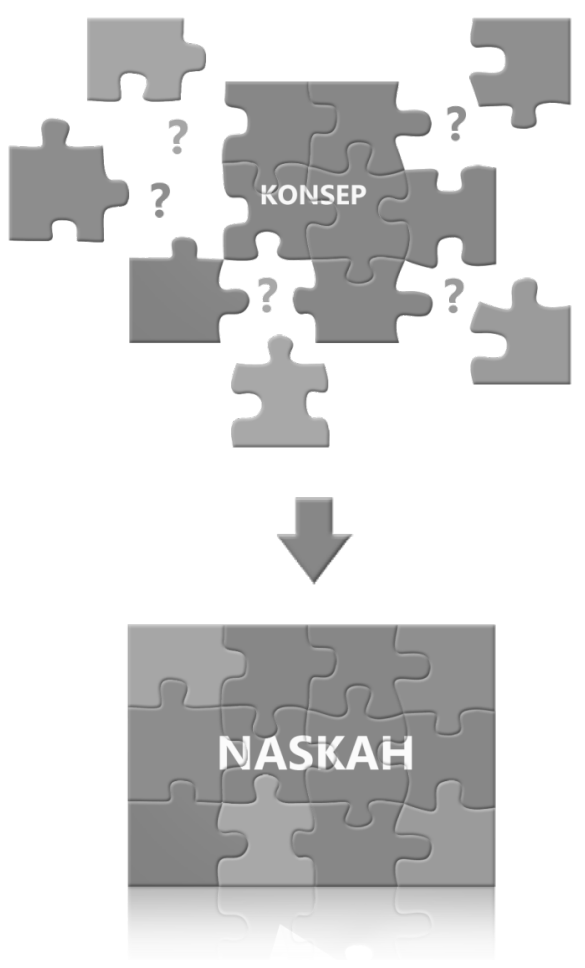

Gambar 4 Teori Puzzle DSKDB Sumber: Aditya Utama, 2013

Hasil olahan tersebut kemudian menghasilkan shooting script yang dijadikan pedoman dalam proses pengeksekusian konsep. Konsep yang akan diwujudkan dalam perancangan ini terbagi menjadi tiga konsep yang masing-masing mewakili tiga isu sosial yang berbeda, yaitu: fanatisme, ketergantungan teknologi, dan perilaku kekerasan.
Alur cerita diawali dengan sebuah gambaran perspektif subjektivitas pencipta terhadap suatu realitas sosial dan diakhiri dengan sebuah konklusi rasional. Closing dalam karya audiovisual ini akan dikemas menggunakan simbol-simbol visual dan meminimalisir pemunculan teks. Closing karya terdiri dari simbol visual dari kesimpulan cerita dan logo Olah Nalar. 


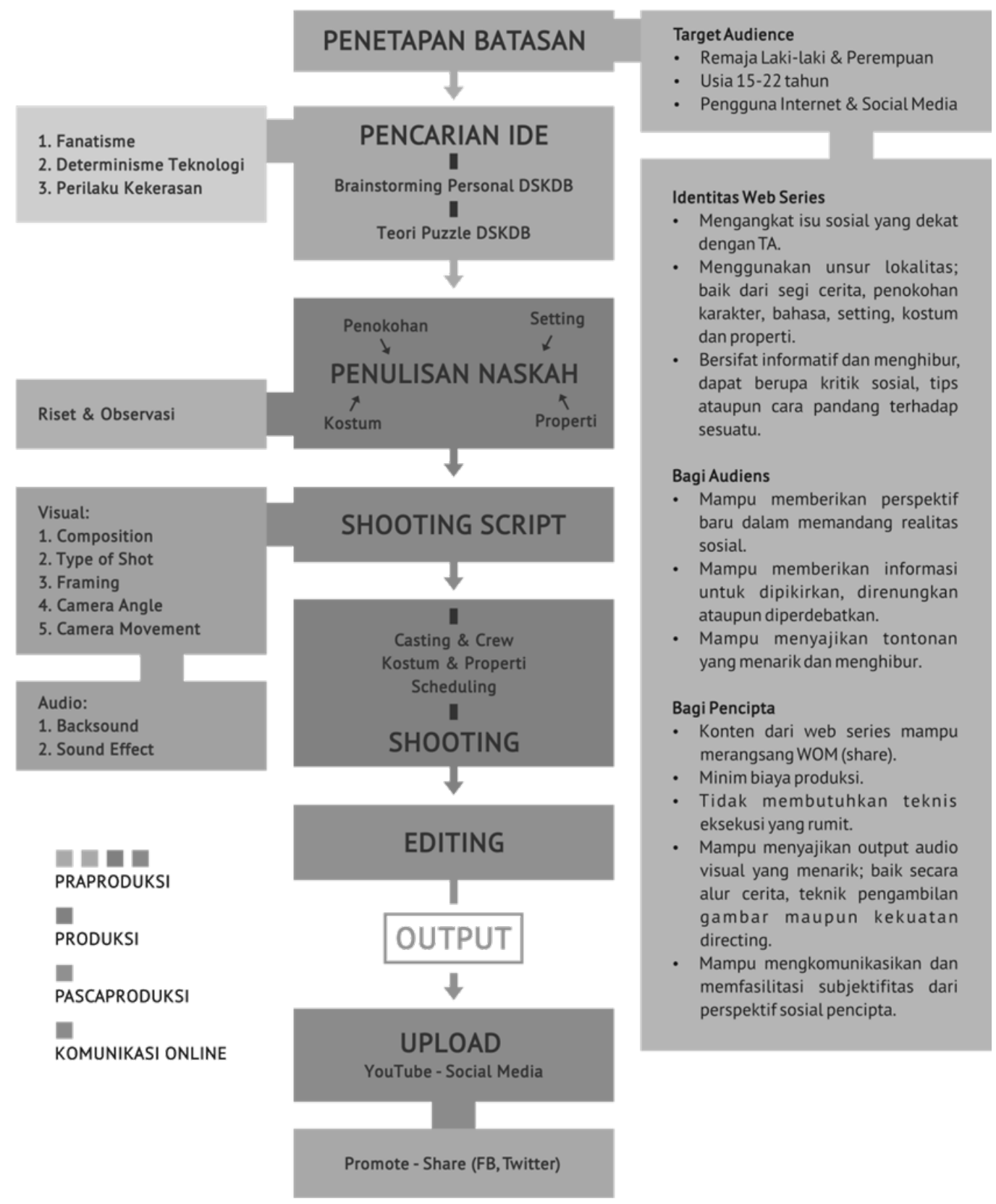

Gambar 5 Proses Perancangan Web Series "Olah Nalar" Sumber: Aditya Utama, 2013

\section{HASIL DAN PEMBAHASAN}

\section{Olah Nalar Episode 1: Merah Glory}

Episode pertama mengangkat topik tentang fanatisme remaja terhadap sepak bola luar negeri. Episode ini menceritakan tentang segerombolan fans remaja yang berusaha memperlihatkan loyalitas dan antusiasmenya terhadap klub sepak bola luar negeri Manchester United (MU) dengan cara menyanyikan salah satu lagu kebangsaan klub tersebut dan merekamnya melalui kamera video. Namun di tengah proses perekaman tiba-tiba datang seorang pengendara sepeda yang iseng mengejek klub MU dan akhirnya mengakibatkan bentrok fisik. 

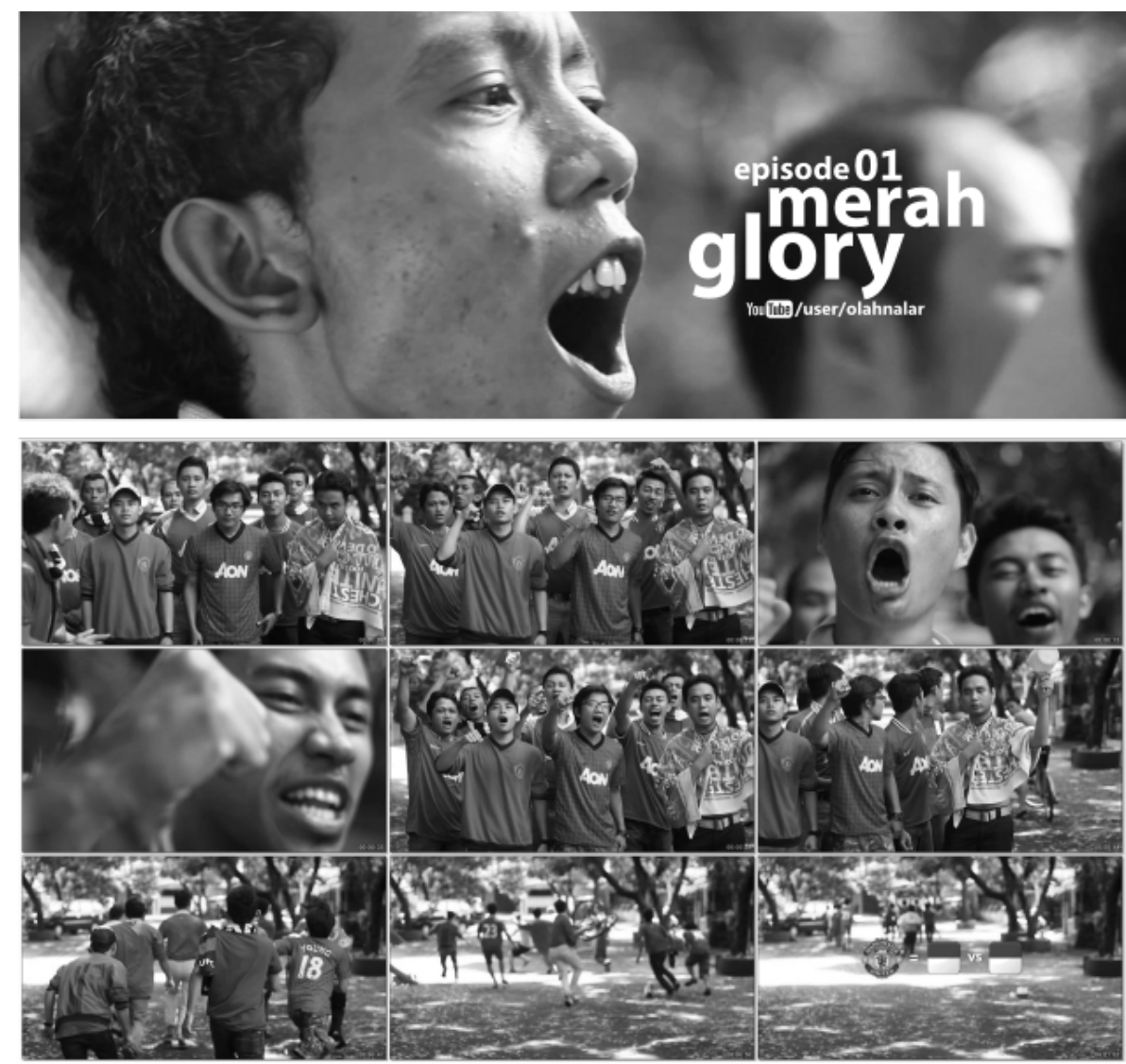

Gambar 6 Screenshot Olah Nalar Episode 1: Merah Glory Sumber: Aditya Utama, 2013

Ada beberapa alasan kenapa memilih klub MU sebagai klub sepak bola luar negeri yang diangkat dalam episode ini. Pertama, MU merupakan salah satu klub sepak bola yang terkenal dan memiliki jumlah fans terbesar di dunia. Oleh karenanya wajar apabila MU diposisikan sebagai contoh kasus. Kedua, salah satu lagu kebangsaan MU berjudul "Glory Glory Man United" memiliki tempo yang cepat dan energik. Hal ini dibutuhkan untuk mendukung intensitas suasana fanatisme yang ingin dibangun, baik secara audio maupun visual.

Ketiga, adanya kemungkinan kontroversi yang akan terjadi ketika episode ini akan diunggah. Secara konsep, episode ini menuntut adanya pemunculan identitas salah satu klub sepak bola luar negeri. Tentunya penggunaan identitas klub mana yang akan dipilih didasarkan pada pertimbangan akan tingginya popularitas klub tersebut di mata remaja Indonesia. Semakin tinggi popularitas klub tersebut semakin baik karena berbanding lurus dengan dampak kampanye yang akan dihasilkan. Sedangkan di sisi lain, penggunaan identitas klub ini juga dapat mengundang respon negatif, terutama dari suporter fanatik klub tersebut yang ada di Indonesia.

Persepsi awal yang muncul, episode ini bisa dianggap sebagai bentuk ejekan untuk klub MU apabila tidak diimbangi dengan episode-episode selanjutnya yang juga 
bermuatan kritik terhadap isu-isu lain seputar lingkungan sosial remaja Indonesia.

Meskipun begitu, kontroversi ini apabila dikelola dengan baik dapat merangsang dialog sekaligus dapat digunakan sebagai alat untuk mengangkat popularitas web series Olah Nalar; terutama dalam episodenya yang pertama.

Secara teknis eksekusi, konsep ini sebenarnya tidak terlalu membebani karena cerita cukup sederhana dan hanya membutuhkan pengambilan single-shot. Namun kendala muncul ketika sebagian besar talent yang digunakan tidak memiliki pengalaman akting dan cenderung memperlihatkan ekspresi yang datar saat menatap ke arah kamera. Solusi yang dilakukan untuk mengatasi permasalahan ini adalah melakukan penataan blocking dengan cara menempatkan talent-talent yang memiliki kemampuan akting kuat (lingkaran putih) dalam sebaran formasi yang merata agar mampu mengangkat kelemahan akting talent lainnya secara visual.

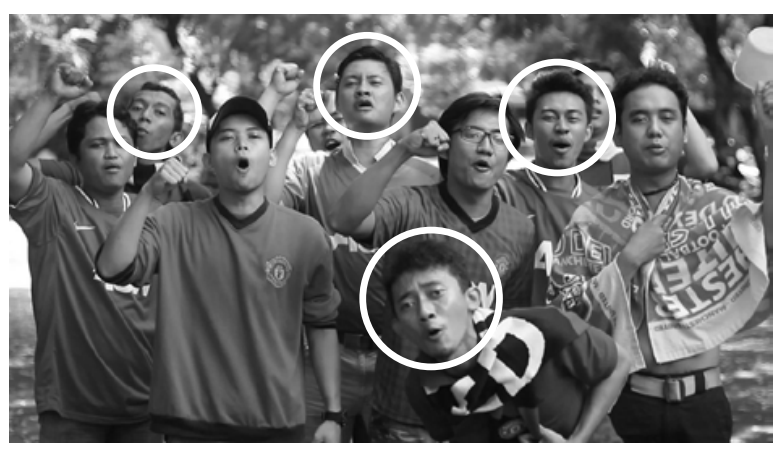

Gambar 7 Penataan Blocking Dalam Produksi Merah Glory Sumber: Aditya Utama, 2013

Secara editing, materi audiovisual yang diolah menghasilkan dua versi output yang sedikit berbeda, yaitu; versi single-shot dan versi multi-shot dengan tambahan insert close up beberapa talent. Setelah melakukan pertimbangan, akhirnya dipilih versi multishot sebagai materi yang akan digunakan. Alasannya adalah dengan penggunaan insert close up, aspek fanatisme yang ingin diperlihatkan terasa lebih kuat dan terkesan lebih dinamis secara visual.

\section{Olah Nalar Episode 2: Cuek BB}

Episode kedua mengangkat topik tentang ketergantungan teknologi BlackBerry yang melanda remaja Indonesia. Episode ini menceritakan tentang dua sahabat perempuan, bernama Nisa dan Fina, yang sedang terlibat dalam pembicaraan di suatu café. Nisa merasa gelisah karena hamil di luar nikah dan berusaha menceritakan permasalahannya kepada Fina. Pembicaraan berjalan cukup lama, namun ternyata Fina tidak memperhatikan ucapan Nisa karena sibuk berinteraksi dengan Vera menggunakan BBM-nya; menggosipkan permasalahan lain. Sadar tidak dihiraukan, Nisa merasa jengkel dan langsung pergi.

Salah satu alasan konsep ini dipilih adalah karena adanya aspek penggunaan angle kamera subjektif yang ada dalam konsep. Penggunaan angle subjektif ini mampu memberikan perspektif unik dan pengalaman langsung bagaimana seseorang terkadang lupa memperhatikan orang yang di dekatnya karena "diperbudak" teknologi. Konsep ini juga dianggap insightful karena mampu merepresentasikan realitas yang ada dalam kehidupan sosial remaja. 

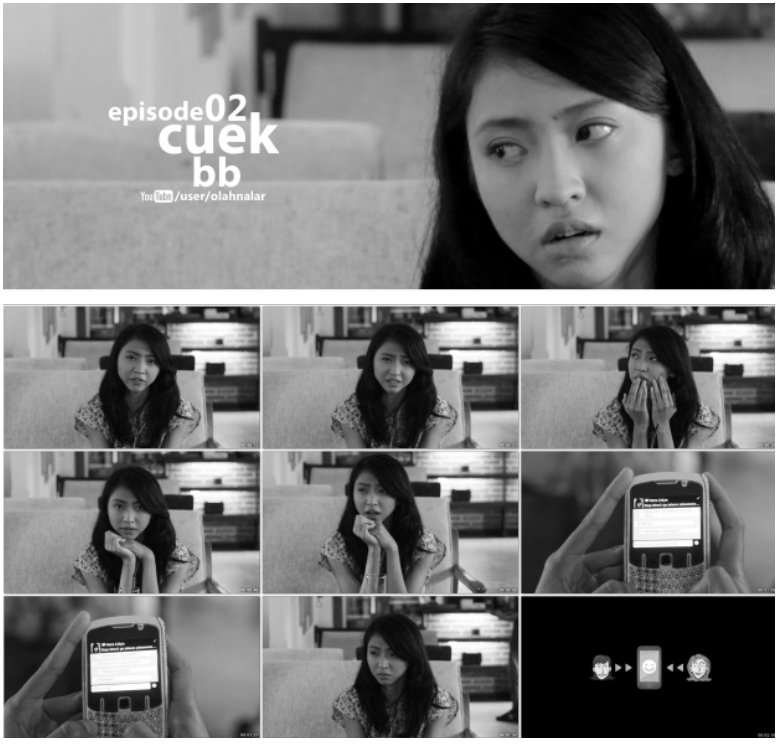

Gambar 8 Screenshot Olah Nalar Episode 2: Cuek $\mathrm{BB}$

Sumber: Aditya Utama, 2013

Dalam tahap praproduksi, proses pembuatan naskah sempat mengalami kendala karena adanya kebutuhan dialog yang merepresentasikan gaya bicara remaja perempuan. Sebagaimana diketahui, gaya bicara dan pilihan kata seorang perempuan berbeda dengan seorang laki-laki. Namun permasalahan ini teratasi dengan cara memberikan keleluasaan interpretasi kepada talent terhadap pengaplikasian naskah. Esensi cerita dialog tetap dipertahankan, namun dengan pilihan kata yang menyesuaikan kebiasaan bicara talent; yang notabene merupakan remaja perempuan.

Variabel lain yang menjadi permasalahan adalah aspek teknikalitas yang dibutuhkan untuk mengeksekusi peralihan fokus dari shot wajah talent 1 ke shot tangan talent 2 yang sedang mengetik BBM. Eksekusi ini akhirnya dilakukan dengan cara menggunakan dua orang untuk mengoperasikan kamera; satu orang bertugas mengatur peralihan fokus lensa, satu orang lagi bertugas mengatur turun-naiknya kamera. Konsekuensinya, fokus directing penulis menjadi menurun karena harus terbagi antara mengoperasikan kamera dan melakukan direksi akting.

Permasalahan lain juga muncul dalam mempertahankan area fokus shot tulisan BBM. Hal ini terjadi karena tidak ada persiapan teknis untuk memberikan tumpuan pada tangan talent 2 yang sedang memegang BB. Konsekuensinya tangan talent 2 sering bergerak dan menyebabkan shot tulisan sering tidak fokus. Permasalahan ini menjadi faktor yang cukup krusial dalam proses pemilihan take shot yang digunakan dalam editing; dari lima hasil take yang bagus, hanya terdapat satu take yang memiliki fokus shot yang relatif stabil pada tulisan BBM. Namun take tersebut memiliki kekurangan dalam aspek pencahayaan karena diambil ketika hari sudah menjelang sore. Konsekuensinya, gambar yang dihasilkan cenderung lebih gelap jika dibandingkan dengan gambar take lainnya.
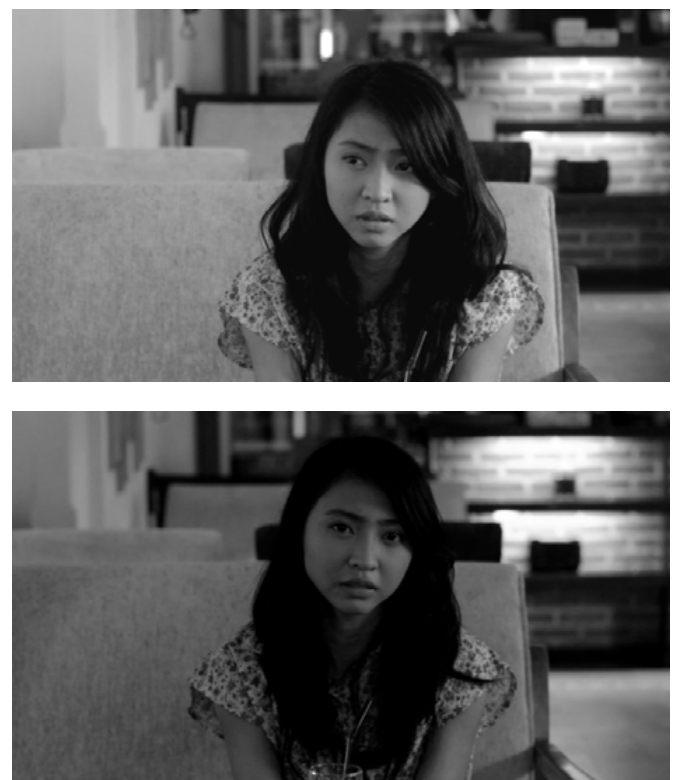

Gambar 9 Perbandingan Pencahayaan Take Shot Sumber: Aditya Utama, 2013 


\section{Olah Nalar Episode 3: Eksperimen Kata}

Episode ketiga mengangkat topik tentang perilaku kekerasan yang telah mengakar dalam kehidupan remaja Indonesia. Episode ini menceritakan tentang ekperimen kata yang dilakukan dua ilmuwan terhadap seorang remaja laki-laki yang temperamen. Eksperimen yang dilakukan cukup sederhana, yaitu menguji dampak kata-kata dalam mempengaruhi perilaku agresif seseorang. Kata-kata yang digunakan cukup bervariasi; mulai dari kata-kata pujian sampai pada katakata makian. Pada awalnya, remaja tersebut sempat merasa bingung membaca kata-kata pujian yang ditunjukkan. Namun seiring dengan pergantian kata-kata yang menjurus ke arah makian, remaja tersebut merasa tersinggung, berteriak-teriak menantang, dan mulai menunjukkan perilaku kekerasan.

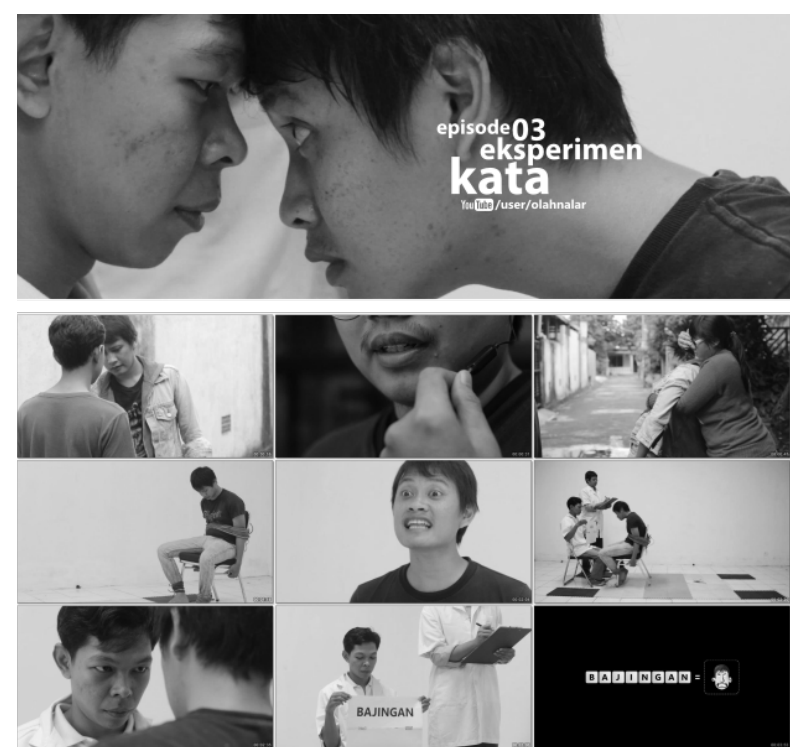

Gambar 10 Screenshot Olah Nalar Episode 3: Eksperimen Kata

Sumber: Aditya Utama, 2013

Konsep ini berusaha mengangkat realitas tentang bagaimana suatu kata tertentu, dengan mudahnya, mampu mempengaruhi perilaku agresif seseorang. Konsep ini menggunakan pendekatan cerita yang exaggeration (melebih-lebihkan) dan situasi yang imajiner. Aspek exaggeration cerita ini sengaja digunakan untuk memberikan kesan "penyangatan" betapa mudahnya suatu kata mampu mempengaruhi perilaku kekerasan seseorang.

Pada awal perumusan ide, cerita dimulai dari ruangan indoor suatu lab. Namun setelah melewati beberapa pertimbangan rasional, akhirnya diputuskan untuk menambah adegan menggunakan scene outdoor untuk mendukung rasionalitas alur cerita dan membangun karakter temperamen remaja tersebut. Dialog yang digunakan sengaja menggunakan bahasa Jawa untuk menghadirkan kesan yang otentik dalam emosi dialog yang ingin ditunjukkan. Selain itu, untuk membantu talent utama; yang merupakan orang Jawa, agar dapat mengartikulasikan dialog secara lebih orisinal.

Secara produksi, konsep ini terbilang cukup berat karena membutuhkan banyak adegan, scene, shot, dan properti dalam pelaksanaannya. Proses perekaman visual dan audio dilakukan secara terpisah karena salah satu scene berada dalam ruangan indoor yang berdengung dan membutuhkan waktu yang cukup lama untuk menyatukannya dalam proses editing.

\section{Eksperimen Dalam Karya}

Perancangan ini mencoba untuk melakukan beberapa eksperimen dalam pengemasan karyanya. Beberapa eksperimen yang dilakukan dalam perancangan ini meliputi: 


\section{Penggunaan gaya persuasi yang halus.}

Pendekatan persuasi dalam karya ini dilakukan secara halus; tidak berusaha mendikte dan mengarahkan suatu perilaku, namun sekedar menyajikan konklusi rasional berdasarkan premis-premis yang telah dijabarkan dalam tayangan.

Hal yang mendasari pemilihan gaya ini adalah pengalaman pribadi penulis sebagai seorang makhluk sosial. Dalam suatu hubungan interpersonal, ada kalanya seseorang dikondisikan untuk memberikan nasehat atau mencoba untuk mempengaruhi sikap dan perilaku seseorang. Gaya dan cara penyampaian masing-masing orang bisa berbeda-beda. Namun ada dua jenis gaya pendekatan yang bisa disimpulkan selama ini, yaitu:

a. Gaya persuasi yang pertama, berusaha mempersuasi dengan cara mendikte:

"kamu salah, harusnya kamu itu bersikap seperti ini.. "

b. Gaya persuasi yang kedua, berusaha mempersuasi secara halus:

"oke, saya tidak berusaha menentangmu, tapi faktanya seperti ini.. keputusan tetap di tanganmu"

Dua-duanya berusaha mempersuasi seseorang dengan cara yang berbeda. Gaya persuasi yang pertama menawarkan arogansi, merasa yang paling benar dan harus diikuti. Satu hal yang penulis pelajari dari pengalaman interpersonal sehari-hari adalah; "sebenar-benarnya ucapan seseorang, kemungkinan besar tidak akan didengarkan apabila diucapkan dengan cara yang arogan" karena pada dasarnya manusia tidak ingin diposisikan di bawah manusia yang lain.
Sedangkan gaya persuasi yang kedua menawarkan kerendahan hati dalam penyampaiannya. Mencoba memposisikan diri setara, hanya sekedar menyajikan argumen dan fakta yang ada. Gaya pendekatan ini terbilang memiliki persentase keberhasilan persuasi lebih tinggi dibanding gaya persuasi yang arogan.

Demikian halnya dengan gaya persuasi konvensional iklan-iklan sosial yang ada selama ini. Sebagian besar cara penyampaian pesannya selalu diakhiri dengan suatu perintah, seperti; “jangan buang sampah sembarangan", “stop korupsi!", dan sebagainya.

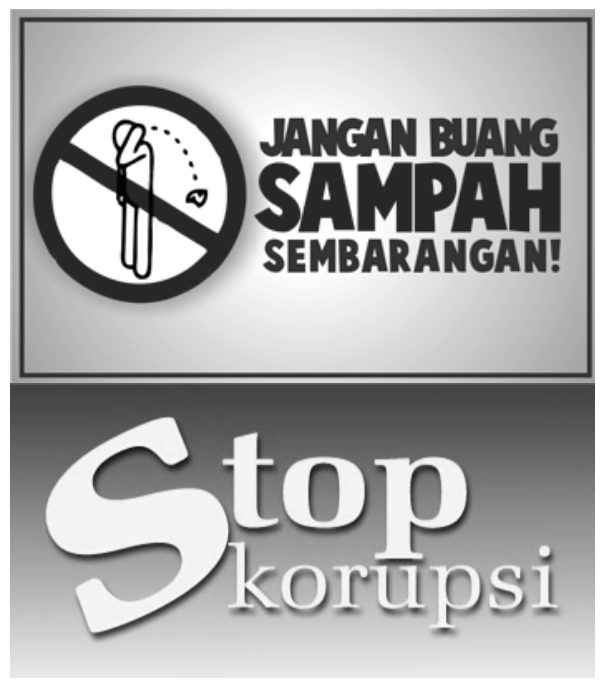

Gambar 11 Gaya Persuasi Konvensional Iklan-Iklan Sosial

Sumber: http://www.google.co.id, diunduh 27 Februari 2015

Ada kecenderungan untuk mendikte dalam penyampaian pesannya. Oleh karenanya, dalam perancangan karya ini, penulis mencoba untuk menggunakan gaya persuasi yang halus dengan cara membangun premis-premis logis dari fakta yang dibentuk oleh cerita dan mengakhirinya dengan konklusi rasional. Tidak diposisikan sebagai 
sesuatu yang bersifat mutlak untuk diikuti, namun cukup menjadi sarana perenungan.

\section{Aspek kredibilitas pesan dibangun melalui fondasi logika.}

Meskipun terdapat polesan imajinasi dalam pengemasan cerita, namun esensi ide cerita tetap mengandalkan fakta dan logika sebagai fondasi pesannya. Aspek imajinasi hanya berperan sebagai penghubung fakta dan pengemas cerita agar lebih menarik.

Fakta dan logika merupakan alat untuk mencapai kredibilitas dan kebenaran. Dengan adanya kedua hal ini diharapkan mampu meminimalisir keraguan pesan yang ada. Fondasi logika dibangun melalui fakta-fakta yang diciptakan dalam cerita. Meskipun sengaja diciptakan, namun fakta ini memang merupakan representasi fakta dari keadaan realitas yang ada di sekitar remaja.

Sebagai contoh dalam karya Olah Nalar episode 1 "Merah Glory", dengan penjabaran fakta sebagai berikut:

a. Benar tidak bahwa banyak remaja Indonesia yang menjadi fans klub Manchester United? Berdasarkan fakta dan riset, jawabannya benar.

b. Benar tidak bahwa ada sebagian masyarakat yang bersikap antipati (haters) terhadap orang-orang yang menjadi fans fanatik klub sepak bola luar negeri? Berdasarkan fakta, jawabannya benar.

c. Benar tidak apabila suatu gerombolan yang memiliki pusat perhatian yang sama (fans MU) dalam intensitas situasi yang tinggi rentan untuk melakukan perilaku agresif? Berdasarkan fakta dan teori, jawabannya benar.

Ketiga fakta tersebut kemudian diciptakan kembali ke dalam fakta cerita:
"Sekelompok fans MU (fakta a) terlihat antusias menyanyikan lagu kebangsaan $M U$, tiba-tiba muncul orang yang iseng mengejek MU (fakta b), merasa tidak terima, kelompok fans tersebut kemudian secara beramai-ramai mengejar dan memukuli orang tersebut (fakta c)."

Berdasarkan fakta-fakta yang tercipta dalam cerita kemudian dapat ditarik premispremis logis sebagai berikut:

\section{Premis 1:}

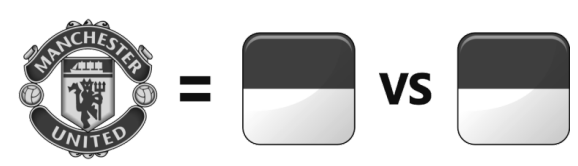

(gara-gara klub MU) (orang Indonesia) (konflik dengan) (orang Indonesia)

Premis ini valid karena secara fakta cerita diperlihatkan bahwa sekelompok fans MU yang berkebangsaan Indonesia mengejar dan memukuli secara beramai-ramai orang Indonesia lainnya karena mengejek klub tersebut.

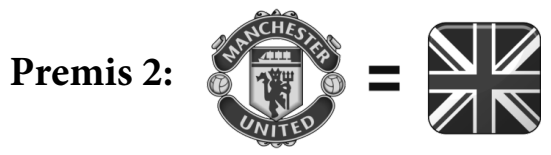

(padahal klub MU) (berasal dari) (Negara Inggris)

Premis ini juga valid karena berdasarkan pada fakta realitas yang ada dan berdasarkan fakta cerita bahwa lagu kebangsaan MU dinyanyikan menggunakan bahasa Inggris.

Kedua premis tersebut kemudian secara implisit berusaha mengarahkan audiens untuk menyimpulkan sebuah konklusi logis: "betapa bodohnya kita sebagai bangsa Indonesia mengadu domba diri sendiri demi kebanggaan pihak asing”. Konklusi 
tersebut memang sengaja tidak diperlihatkan dalam tayangan karena premis-premis yang dihasilkan dinilai sudah mampu mengarahkan audiens untuk menuju ke arah konklusi tersebut secara impulsif.

\section{Closing karya dikemas menggunakan simbol-simbol visual.}

Closing karya terdiri dari simbol visual dari kesimpulan cerita, meminimalisir pemunculan teks, dan diakhiri dengan logo Olah Nalar. Berikut adalah pengaplikasian closing visual dalam ketiga episode web series Olah Nalar:
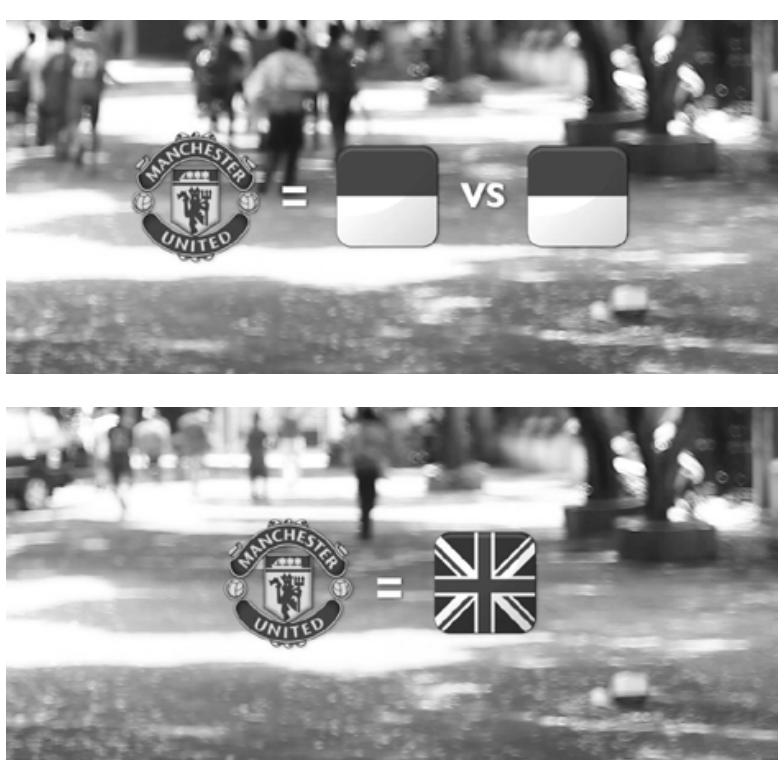

Gambar 12 Closing Visual, Episode 1: Merah Glory Sumber: Aditya Utama, 2013
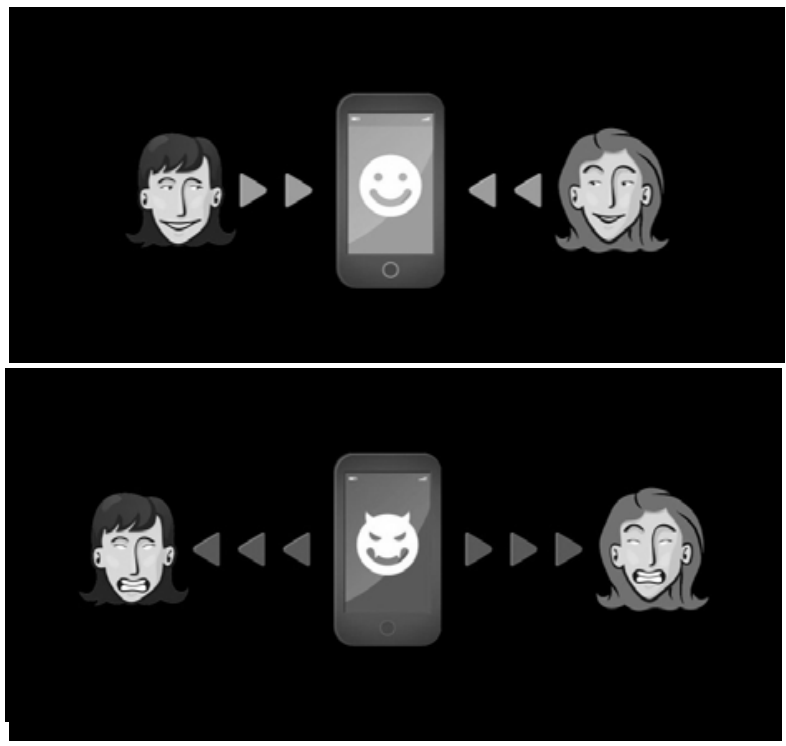

Gambar 13 Closing Visual, Episode 2: Cuek BB Sumber: Aditya Utama, 2013
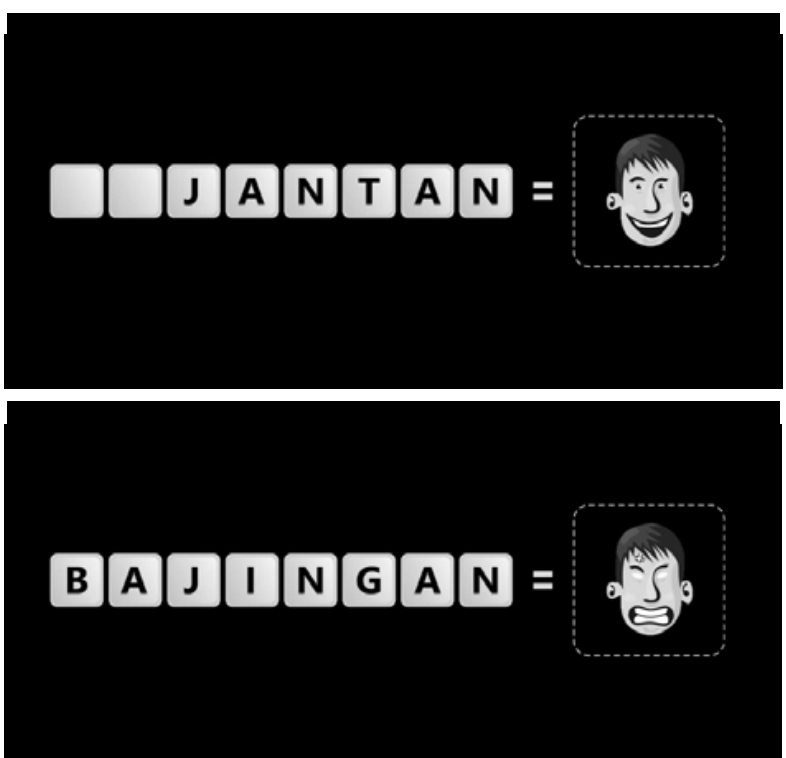

Gambar 14 Closing Visual, Episode 3: Eksperimen Kata

Sumber: Aditya Utama, 2013

Salah satu alasan yang melatarbelakangi eksperimen ini adalah hipotesis bahwa visual memiliki kemampuan reminding yang lebih kuat dibandingkan teks. Hal ini dapat dibuktikan dengan menganalisis memori keseharian, sebagai berikut: 
"Dalam keseharian, ketika anda mengingat teman anda apa yang terlintas pertama kali dalam ingatan anda? Apakah rangkaian huruf dari namanya atau visual dari wajah/fisik teman anda?"

"Ketika saya mengucapkan nama Arnold Schwarzenegger, apa yang terlintas pertama kali dalam benak anda? Apakah rangkaian huruf nama yang terdiri dari A R N OL D SCH $W A R Z E N E G G E R$ atau visual wajah/fisik dari Arnold Schwarzenegger? Bahkan bisa jadi anda tidak tahu ejaan hurufnya karena merasa asing dan malas untuk mengingat seperti halnya saya yang harus melakukan googling terlebih dahulu untuk memperoleh ejaan yang benar."

Hasil jawaban ini memang tidak dapat digeneralisasikan dengan mudah karena masing-masing orang memiliki preferensi dan tendensi penggunaan otak kiri dan otak kanan yang berbeda. Namun ada kecenderungan bahwa pengalaman visual lebih berdampak dalam memori dibanding pengalaman tekstual dan ada kecenderungan untuk mengedepankan memori visual dibandingkan memori tekstual ketika mengingat sesuatu.

Argumen lainnya adalah teks untuk terbaca dan menyampaikan pesan harus menyertakan beberapa komponen huruf, konsekuensinya banyak huruf yang digunakan untuk mengungkap suatu maksud. Sedangkan gambar visual, meskipun terkadang memiliki komponen gambar yang banyak, namun gambar visual cenderung membentuk satu kesatuan objek yang tunggal. Jadi lebih mudah diingat.
Selain itu, huruf sudah menjadi suatu hal yang tidak istimewa lagi karena terpaannya sangat banyak dalam kehidupan sehari-hari. Bahkan sebagian besar iklan audiovisual layanan masyarakat selalu mengandalkan teks sebagai penyampaian konklusi pesannya. Hal ini mengakibatkan huruf sebagai suatu pengalaman estetis menjadi tidak menarik lagi. Sedangkan ruang memori untuk closing visual masih terbuka lebar.

Penulis menyadari bahwa eksperimen ini cukup beresiko mengingat hal ini sangat erat kaitannya dengan kelancaran proses penyampaian pesan dan persepsi audiens. Namun resiko tersebut coba diminimalisir dengan cara memberikan tambahan teks keterangan closing dalam fasilitas caption yang ada di YouTube.

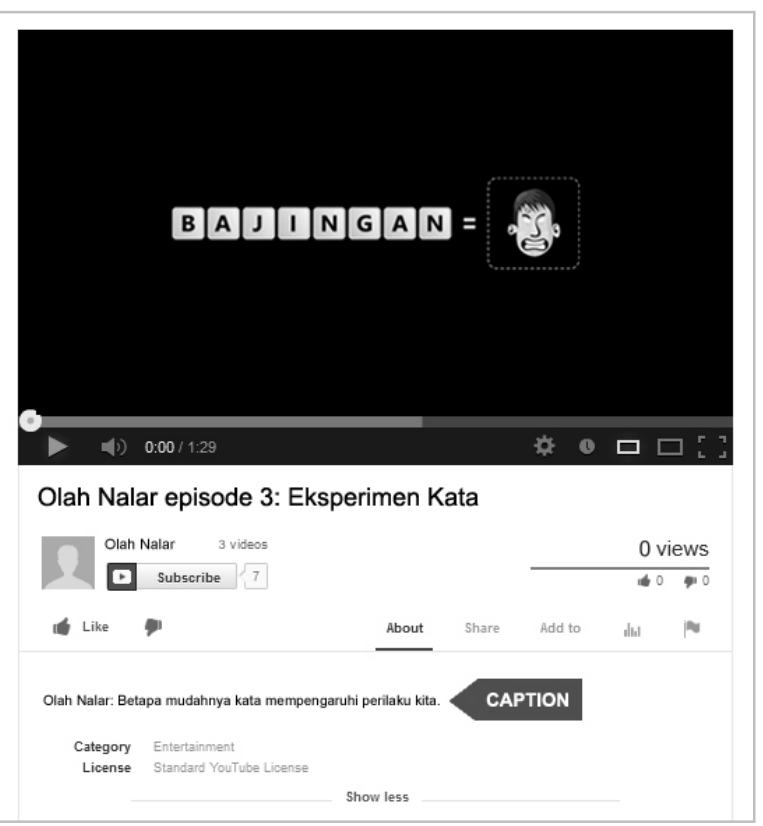

Gambar 15 Fasilitas Caption YouTube Sumber: Reproduksi Aditya Utama, 2013

Selain itu, untuk menguji keterbacaan pesan yang disampaikan melalui closing visual, penulis juga melakukan focus group 
discussion (FGD) bersama 12 orang remaja dengan kisaran usia 19-20 tahun. Hasil yang diperoleh adalah 10 orang remaja mengaku memahami maksud pesan yang ingin disampaikan dan bisa mengutarakannya secara lisan, sedangkan 2 orang lainnya mengaku memahami maksud pesan yang ingin disampaikan namun kesulitan untuk menjelaskannya secara lisan.

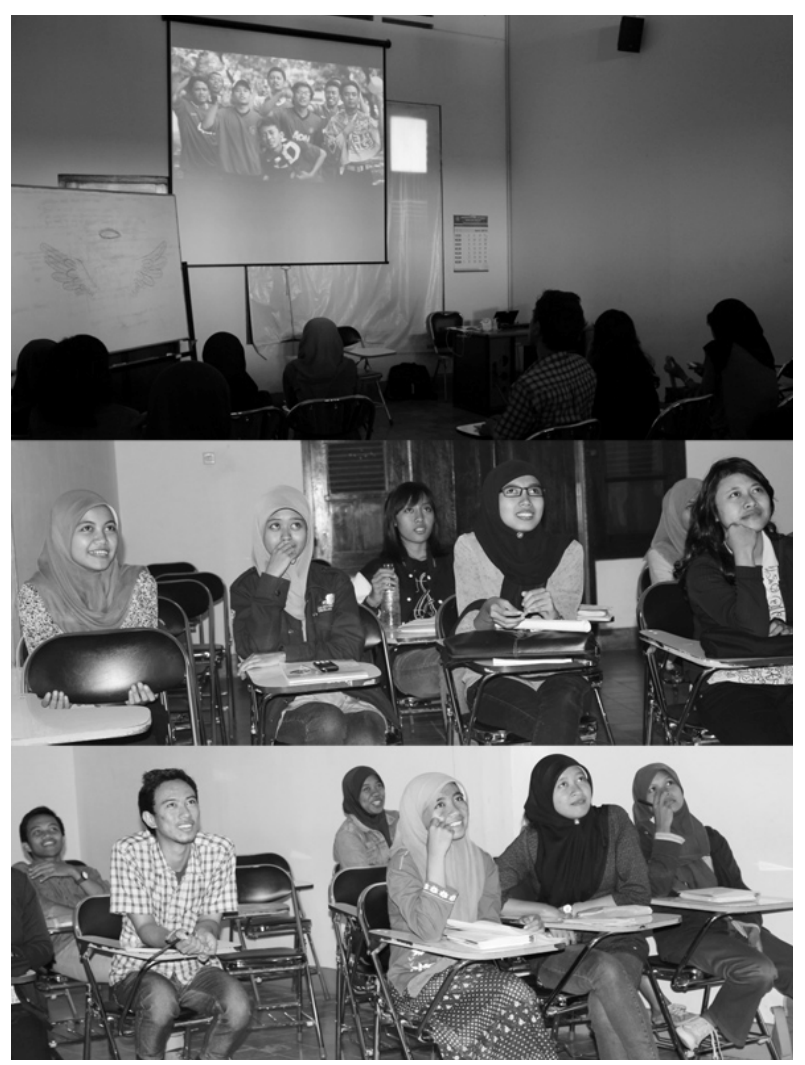

Gambar 16 Foto Dokumentasi Focus Group Discussion Sumber: Aditya Utama, 2013

Pengujian secara langsung juga telah dilakukan untuk melihat respon publik dengan cara melakukan sharing link tayangan Olah Nalar di account Facebook pribadi penulis. Berdasarkan jumlah like dan comment selama 2 hari (tanggal 26-27 Juli 2013), respon yang diperoleh rata-rata positif. Sharing link tersebut memperoleh 33 likes dan dari 23 comment yang ada, tidak ada komentar yang memperlihatkan ketidakpahaman terhadap maksud dari konten tayangan.
Kesimpulan sementara menunjukkan bahwa pesan dan maksud yang ada dalam tayangan tersampaikan dengan baik dan dapat dipahami. Selain itu, dari data yang terdeteksi, beberapa orang juga melakukan inisiatif untuk melakukan sharing link tayangan Olah Nalar di account-nya masingmasing, baik itu melalui media sosial Facebook, Twitter maupun Google+. 


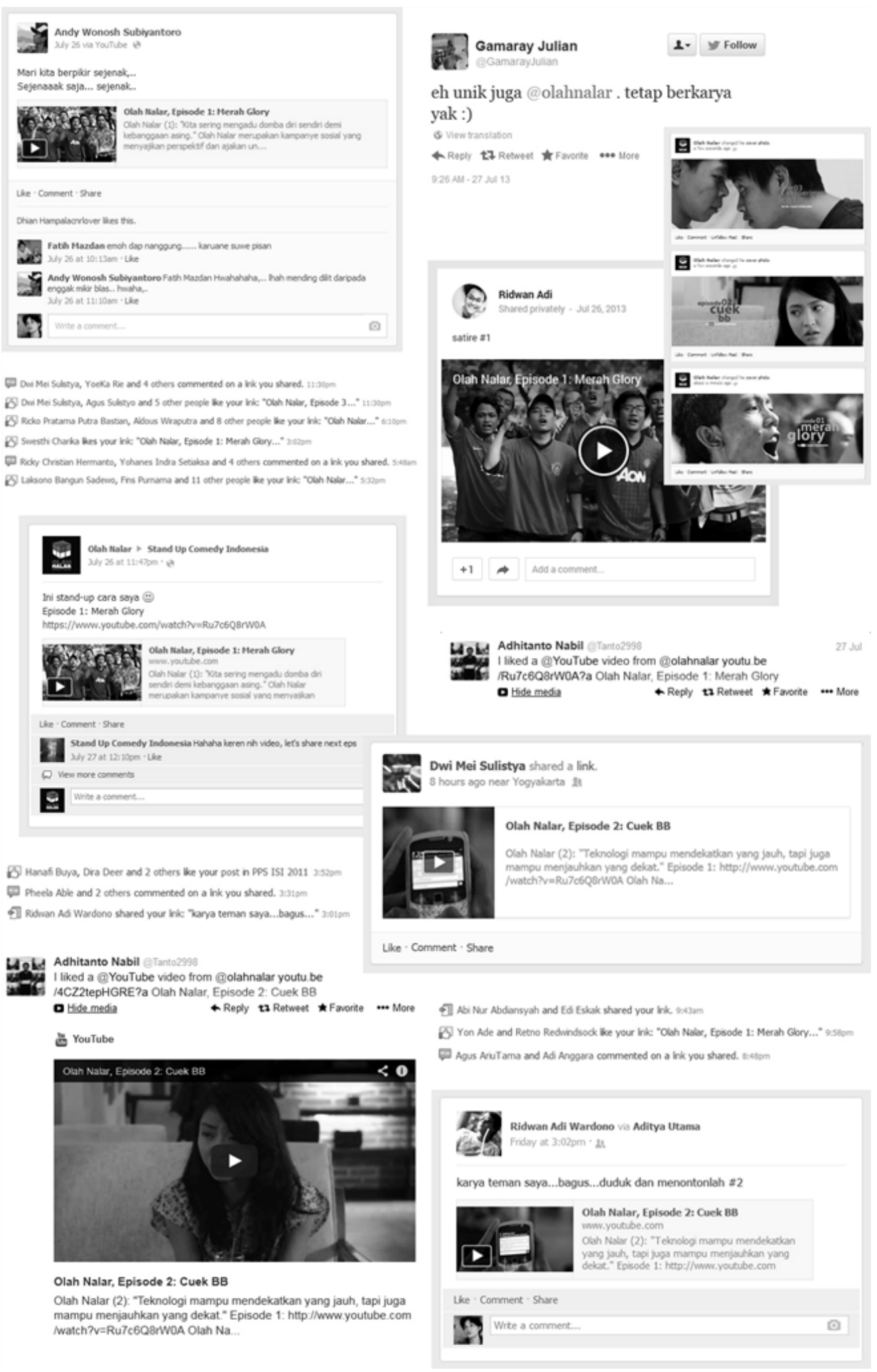

Gambar 17 Sharing Link Tayangan Olah Nalar Inisiatif Orang Lain Sumber: Reproduksi Aditya Utama, 2013 


\section{PENUTUP}

\section{Kesimpulan}

Merancang sebuah kampanye sosial menggunakan platform media web series membutuhkan tahapan proses yang cukup panjang. Selain harus memikirkan pengolahan ide dan penyampaian pesan, dibutuhkan juga kemampuan dan persiapan yang matang untuk mengeksekusi konsep serta melakukan perencanaan media yang terarah.

Dalam prosesnya, karya ini berusaha menyajikan aspek kebaruan dalam melakukan pendekatan persuasi kepada audiens dengan melakukan beberapa eksperimen seperti penggunaan gaya persuasi yang halus dalam penyampaian pesan, mengandalkan aspek logika sebagai fondasi kredibilitas pesan, dan penggunaan closing visual di akhir setiap tayangannya.

Karya ini tidak diposisikan sebagai solusi utama untuk mengatasi permasalahanpermasalahan sosial yang ada, namun sekedar mengajak kaum remaja agar berpikir secara lebih kritis, cerdas, dan rasional dalam menghadapi isu-isu sosial yang ada di lingkungan sekitarnya. Harapannya, perspektif logis yang terkandung dalam tayangan ini mampu memberikan kesadaran baru yang dapat menata cara pandang dan perilaku remaja untuk menjadi pribadi yang lebih baik lagi secara individual maupun sosial.

\section{Saran-Saran}

Meskipun bidang disain komunikasi visual cenderung bergerak dalam ranah komunikasi massa, namun ada baiknya juga mempelajari aspek komunikasi interpersonal sebagai pertimbangan dalam cara berkomunikasi.

Masyarakat sekarang tidak sepolos dulu. Mereka tidak mudah terpengaruh oleh iklan. Iklan konvensional sering dianggap semenamena karena sering melakukan komunikasi satu arah; menganggap audiens itu bodoh dan mudah terpersuasi.

Trend sekarang lebih menganjurkan untuk lebih memanusiakan audiens. Menggunakan cara-cara interaktif yang mampu mengundang keterlibatan audiens. Jangan dibiasakan terbawa alur pada kecenderungan-kecenderungan komunikasi yang sudah ada. Jadikan komunikasimu lebih menarik, berbeda, dan menonjol.

Dunia komunikasi berjalan secara dinamis. Perbanyak eksperimen komunikasi dan eksplorasi media. Ketika semua berbicara dengan cara yang sama, pikirkan bagaimana berbicara dengan cara yang berbeda.

\section{DAFTAR PUSTAKA}

[1] Alternatif Baru menonton Film Seri via Internet. http://www.koranjakarta.com/in dex.php/detail/view01/95178. (Diakses tan ggal 24 September 2012)

[2] Hurlock, E.B. (1998). Perkembangan Anak, Terjemahan Soedjarmo \& Istiwidayanti. Jakarta: Penerbit Erlangga.

[3] Mayfield, Antony. (2008). What is Social Media?. iCrossing. (Diakses tanggal 12 Agustus 2013)

[4] Rapar, Jan Hendrik. (1996). Pengantar Logika, Asas-asas Penalaran Sistematis. Yogyakarta: Penerbit Kanisius.

[5] Santrock, J. W. (2001). Adolescence: Perkembangan Remaja, Edisi Ke-6. Jakarta: Penerbit Erlangga. 